\title{
The New Precariousness: Temporary Migrants and the Law in Canada
}

Sarah Marsden

True or False[?] If you are an undocumented worker in Canada, you are an illegal immigrant.

This is true: There are laws to protect Canada and to make sure everyone who wants to come here is treated fairly. You must follow these laws or you will be asked to leave.

The facts: Undocumented workers are illegal immigrants.

The statement above, from the Web site of Citizenship and Immigration Canada, ${ }^{1}$ presents the federal government's current position on undocumented workers ${ }^{2}$ in Canada using the language of illegality. Framing undocumented migrants as "illegal" is part of a shift toward greater attention to undocumented labour migration in Canada as an infringement on sovereignty from inside Canada, in tandem with differential allocation of rights and entitlements between permanent residents and residents with less than permanent migration.

Drawing on the work of Leah Vosko and Luin Goldring, I start by offering the notion of "precarious migration status" as a framing concept for analysis of migration law in Canada, followed by a brief discussion of the history of regulating precarious migrants. Using the notion of precarious status to combine legally distinct categories of migrants on the basis of their relationship to the state and membership entitlements, I argue that there is an increase in migrant precariousness concurrent with a liberalizing shift in Canadian migration law. I then examine two recent changes in migration law in terms of their impact on migrant precariousness. Finally, I offer a critique of the traditional liberal argument for migrant rights, inviting an

1 Citizenship and Immigration Canada, "True or False?" (Ottawa: Citizenship and Immigration Canada Media Centre, 2008), http://www.cic.gc.ca/english/department/ media/facts/workers.asp.

2 For the purposes of this article, several separate but related terms are used to describe the status of non-permanent migrants: the terms "undocumented migrants" and "undocumented workers" refer to people in Canada without current migration status, and the term "irregular migrants" refers to people in Canada who are not in compliance with the law or with any term of their authorization (including undocumented migrants as well as those with documentation who are not in compliance with any aspect of their permit). The term "illegal migrants" is used not to describe migrants per se but, rather, to explore the use of this concept within government policy and its broader discursive function.

Canadian Journal of Law and Society / Revue Canadienne Droit et Société, 2012,

Volume 27, no. 2, pp. $209-229$. doi:10.3138/cjls.27.2.209 
alternative approach to re-embed the phenomenon of precarious migration in its economic context and to establish migrant rights on the basis of economic participation.

\section{Precariousness as an Organizing Concept for Legal Analysis}

Precariousness in the Canadian labour market is described by Vosko in terms of "limited social benefits and statutory entitlements, job insecurity, low wages, and high risks of ill-health." ${ }^{3}$ Vosko notes the essential role of particular economic and political conditions in combination with social stratification on the basis of factors such as gender and race. ${ }^{4}$ Migration status has a similar function: many authorized temporary foreign workers have limited labour mobility through the operation of the Immigration and Refugee Protection Regulations. ${ }^{5}$ Differential entitlements to social protection also occur on the basis of status. ${ }^{6}$ Wage disparity, poor working conditions, and inability to unionize are also well documented. ${ }^{7}$ For undocumented workers, these effects are greatly amplified. Through law, the state thus "creates a variety of different migration statuses, some of which are highly precarious, that in turn produce a differentiated supply of labour that produces precarious workers and precarious employment norms."

Precarious migration status provides a lens for analysis of the effects and functions of the law because it uses a category that is itself defined not by law but, rather, by the fact and degree of exclusion occasioned by legal distinctions: an alternative to accepting "legal" and "illegal" as the primary terms of reference. ${ }^{9}$ Conditions such as labour vulnerability and access to social

L.F. Vosko, Precarious Employment: Understanding Labour Market Insecurity in Canada (Montreal: McGill-Queen's University Press, 2006), 3.

Ibid.

Immigration and Refugee Protection Regulations, SOR/2002-227, s 185(b)(ii).

See, e.g., Health Insurance Act, RSO 1990, c H6. Status-based distinctions may also be due to conditions of the work permit-in the case of access to Employment Insurance, for example, foreign workers may have more difficulty proving "availability for work" if their work permit is bonded to one employer. Employment Insurance Act, SC 1996, c 23, s 18; Service Canada, "Digest of Benefit Entitlement Principles" (Ottawa: Service Canada, 2012), http://www.servicecanada.gc.ca/eng/ei/digest/10_10_0.shtml\#a10_10_8.)

7 See, e.g., M. Sargeant and E. Tucker, "Layers of Vulnerability in Occupational Safety and Health for Migrant Workers: Case Studies from Canada and the UK," Policy and Practice in Health and Safety 2 (2009), 51; K. Preibisch, "Pick-Your-Own-Labor: Migrant Workers and Flexibility in Canadian Agriculture," International Migration Review 44, 2 (2010), 404; Human Resources and Skills Development Canada, "Seasonal Agricultural Worker Program" (Ottawa: HRSDC, 2009), http://www.hrsdc.gc.ca/eng/workplaceskills/ foreign_workers/ei_tfw/sawp_tfw.shtml; L. Binford, "From Fields of Power to Fields of Sweat: The Dual Process of Constructing Temporary Migrant Labour in Mexico and Canada," Third World Quarterly 30, 3 (2009), 503; "Live-In Caregiver Program" (Ottawa: HRSDC, 2012), http://www.hrsdc.gc.ca/eng/workplaceskills/foreign_workers/ lcpdir/lcpone.shtml; P. Hsiung and K. Nichol, "Policies on and Experiences of Foreign Domestic Workers in Canada," Sociology Compass 4, 9 (2010), 766.

8 J. Fudge, "The Precarious Migrant Status and Precarious Employment: The Paradox of International Rights for Migrant Workers" (Metropolis British Columbia Working Paper Series No. 11-15, 2011), 6 .

9 Conceptualizing migration status in terms of illegality as a causative factor resulting in lack of access to rights and entitlements fails to consider the production of different types of legality by the state's constitution of migrant status and the effect on the conditions of 
services serve as the binding characteristic between migrant groups, cutting across the dichotomy of status/non-status and across qualitative distinctions made by legal regulation and policy rhetoric. ${ }^{10}$ This allows us to shift the focus away from scrutinizing the moral legitimacy of entry to assessing potential membership claims for those who are already here. The effects of lessthan-permanent residence on migrants should be of concern to a liberal democracy that purports to maintain equal rights for those within its territory: I argue below that there is good reason to believe that the Canadian workforce includes at least 300,000 people with precarious migration status and that this number is likely to increase, particularly on the more vulnerable end of the spectrum. ${ }^{11}$ If precarious migrants constitute a large and growing proportion of Canada's population, there is a pressing need to critically assess whether, and on what basis, it is justifiable to exclude such people from social membership.

\section{Regulating Precarious Migrants in Canada: History and Context}

Although both labour migration and selective or outright discriminatory entry requirements have been prevalent features of Canadian migration policy throughout its history, large-scale concern about "illegal migrants" per se within Canada arose for the first time in the early 1970s. Although it is beyond the scope of this article to provide a detailed history of Canadian migration policy, ${ }^{12}$ this section offers a basic overview of the major directions of migration policy in order to situate the issue of "illegal migration" alongside a definitive shift toward more a liberal migration regime and the concurrent legal entrenchment of economic viability as the basis for permanent membership in Canadian society.

labour and labour market position: see B. Anderson, "Migration, Immigration Controls and the Fashioning of Precarious Workers," Work, Employment and Society 24, 2 (2010), 306.

10 For example, the legal distinction between the "legitimate refugee" and the "economic migrant 7 bogus refugee" is often employed to justify restrictions within the inland refugee process and on potential temporary entrants from abroad. In the context of refugee law and government rhetoric, the "legitimate refugee" is constructed as a person fleeing persecution and violence, with no economic motivation to enter Canada, while the "economic migrant/bogus refugee" is constructed, in opposition, as a person whose primary basis for entering Canada is to improve his or her material conditions (a highly desirable characteristic in permanent and temporary migrants who are not refugees). In reality, the two may be entwined in ways not easily susceptible to this simple distinction. It is likely that many migrants entering Canada through the inland refugee process experience some combination of persecution and economic desperation, and, similarly, foreign workers may be motivated by risk-based factors not limited to the economy of the sending country.

11 Precarious migration status may also function similarly to racialization in terms of the longevity of its effects; there is evidence even after obtaining permanent residence, many migrants who experienced precarious status continue to experience its detrimental effects. P. Landolt and L. Goldring, "The Long Term Impacts of Non-Citizenship on Work: Precarious Legal Status and the Institutional Production of a Migrant Working Poor (Paper presented at York University, September 16, 2010), http://www.yorku.ca/ raps1/events/pdf/Landolt_Goldring.pdf.

12 For a detailed treatment of the history of Canadian migration policy see N. Kelley and M.J. Trebilcock, The Making of the Mosaic: A History of Canadian Immigration Policy (Toronto: University of Toronto Press, 2010). 


\section{Sarah Marsden}

Starting in the late 1960s, Canada's migration policy underwent prima facie liberalization, characterized by the removal of explicitly racist laws, the introduction of procedural safeguards, and the acceptance of large numbers of refugees on humanitarian (i.e., non-economic) grounds subsequent to the 1969 ratification of the 1951 Convention relating to the Status of Refugees. In 1967, the "points" system of permanent residence was established, by which foreign nationals could migrate to Canada as part of an economic class by proving their potential for economic integration through formal education, language skills, and work experience. Family-class numbers decreased starting in the 1970s, and economic-class numbers increased. ${ }^{13}$ For the first time, the primary nexus of membership in the Canadian nation as a permanent resident referred not to national, ethnic, or familial ties but to the economic potential of the individual. Concurrent with the shift toward an economic nexus for permanent residence was the initiation of a large-scale temporary labour migration program. Historically, Canada had temporary migration programs for targeted countries of origin and labour segments as far back as the 1910s, but the numbers were limited relative to permanent migration. The Non-Immigrant Employment Authorization Program, which began in 1973, was the predecessor of present-day temporary work programs, allowing employers to hire foreign workers on the basis of labour-market need from any country of origin and across a wide range of labour segments; the number of temporary workers often rivalled or exceeded the number of economic-class permanent residents entering Canada. ${ }^{14}$

Although these legal and policy changes signalled the adoption of liberalized migration policies in terms of the removal of racist language and the shift from ethnic to economic preferences, the ongoing racialization of migrants in the application of migration policy is well documented. ${ }^{15}$ Rather than existing in a dichotomous relationship, the racialization of migration and the economic logic of migration are closely enmeshed. The liberalization of migration law did not effectively ameliorate race, class, and gender-based labour stratification precisely because it did not address the underlying economic basis of migration policy. The elision of liberalizing language with the neo-liberal shift to the economic and individualized basis for migration made for a transition in which such stratification persisted as an aspect of migration policy

13 A.T. McLaren and T.L. Black, "Family Class and Immigration in Canada: Implications for Sponsored Elderly Women" (Research on Immigration and Integration in the Metropolis Working Paper Series No. 05-26, 2005).

14 N. Sharma, "On Being Not Canadian: The Social Organization of 'Migrant Workers' in Canada," Canadian Review of Sociology 38, 4 (2001), 425.

15 D.K. Stasiulis and A.B. Bakan, Negotiating Citizenship: Migrant Women in Canada and the Global System (Toronto: University of Toronto Press, 2005); N. Sharma, Home Economics: Nationalism and the Making of "Migrant Workers" in Canada (Toronto: University of Toronto Press, 2006); V. Satzewich, Racism and the Incorporation of Foreign Labour: Farm Labour Migration to Canada since 1945 (London: Routledge, 1991). 
consistent with the operation of capitalist economics ${ }^{16}$ and, in particular, with regard to neo-liberal economic policy. ${ }^{17}$

In the early 1970s, the Canadian state also turned its attention for the first time to the issue of large numbers of what it termed "illegal" migrants (i.e., migrants without valid authorization to reside in Canada) living in Canada, estimating an undocumented population of 200,000 in 1973 , most of whom had entered Canada legally as visitors or workers. The government offered a one-time regularization program to undocumented migrants in 1973, and more than 39,000 people were regularized under its auspices. ${ }^{18}$ By the early 1980s, although estimates of numbers had been reduced, "illegal" migration had come to the attention of the state once again, and eventually another amnesty was offered, regularizing approximately 4,000 people.

The pattern of state and public attention to "illegal" migration since the early 1970 s has been aptly described as making undocumented migration a "sometime social issue" in Canada; that is to say, it is not only the actual fluctuation of the undocumented population but the characterization of "illegal" migrants in terms of their moral lack of entitlement to membership in Canada that is politically determinative. Norm Buchignani describes the division of such migrants into two classes in the public consciousness: meritorious (though undocumented) industrious workers and deserving "compliant" refugees, on the one hand, and "bogus refugees" or "queue jumpers," on the other hand. ${ }^{20}$ In this analysis, the presence of irregular or precarious migrants is not viewed as a problem in itself, but the notions of unfairness and illegality are deployed to condemn migrant groups that deviate from the imagined status quo of the deserving migrant. Thus, while there was considerable public support for amnesty in the 1970s, by the 1980s the perceived higher number of inland claimants came to appear "threatening, inauthentic and large," 21 which led to a decline in public support for an amnesty and controversy over backlog-clearance programs subsequent to the Supreme Court of Canada's landmark decision in Singh $v$ Minister of Employment and Immigration, ${ }^{22}$ which effectively made it mandatory to provide a full oral hearing for inland refugee claimants.

In a state-commissioned report from the early 1980s, the effect of "illegal" migrants is articulated as follows:

16 R. Cohen, Migration and Its Enemies: Global Capital, Migrant Labour and the nation-State (Aldershot, UK: Ashgate Publishing, 2006).

17 R. Munck, C.U. Schierup, and R.D. Wise, "Migration, Work, and Citizenship in the New World Order," Globalizations 8, 3 (2011), 249.

is D.S. North, Amnesty, Conferring Legal Status on Illegal Immigrants: The Canadian Experience, the Western European Experience, and Some Comments on Its Possible Consequences in the US (Washington, DC: Center for Labor and Migration Studies, New TransCentury Foundation, 1982), A-28.

19 N. Buchignani "Vanishing Acts: Illegal Immigration in Canada as a Sometime Social Issue," in Illegal Immigration in America: A Reference Handbook, ed. David Haines and Karen Rosenblum (Westport, CT: Greenwood Press, 1999). Ibid., 434.

21 lbid.

22 Singh v Minister of Employment and Immigration, [1985] 1 SCR 177. 


\section{Sarah Marsden}

Many Canadians wrote to express their views as to the deleterious effect of illegals on the economy and, particularly, in relation to unemployment, the burden on welfare and the failure to pay taxes. However, in the absence of better evidence, it is far from clear that such adverse consequences do occur. The most obvious consequence of illegal migration to Canada is that our carefully established and administered selection criteria are not applied ... the greatest negative feature of illegal migration to Canada may be its impact on the integrity of our country.

From a somewhat different angle, this conclusion fits with Buchignani's analysis as well: the presence of "illegal" migrants within Canada is problematic primarily because it represents a breach of national integrity and an offence to the principles of sovereignty, not because it has any measurable detrimental effect. In contrast to policy rhetoric, the function of immigration law in conjunction with the market economy appears to promote irregular migrant populations, resulting in a situation in which such migrants are "unwelcome but tolerated."

Precarious migration thus emerges as the indispensable shadow of the economic nexus of membership and gives rise to what Donald Galloway calls liberalism's "basic dilemma" of maintaining an economically beneficial resident population with no political voice and differential access to the social and economic benefits of membership. ${ }^{25}$ Although liberal values prescribe inclusion and non-discrimination, sovereignty is deployed to defend the absolute right of the state to determine membership, which is constructed as a necessary precursor of the "right to have rights." Crucially, this right is often justified on the basis of border protection and restricting entry, but in the case of precarious migration, exclusionary measures are applied to people who already reside here and are supported by constructions such as the "bogus refugee" or "illegal migrant"-the illiberal tendencies of liberal states. ${ }^{27}$ Focusing on precarious migrants as a population per se promotes an embedded understanding of the law by underscoring the tensions and exclusions evident in the liberal/neo-liberal policy conjunction that has driven Canada's migration policy since the early 1970s. Precarious migrants provide economically essential labour while being constructed as the Other of regularized migrants or citizens through racialization, criminalization, or other forms of exclusion. ${ }^{28}$ This exclusion is premised on a view of

23 W.G. Robinson, Illegal Migrants in Canada: A Report to the Honourable Lloyd Axworthy (Hull: Minister of Supply and Services Canada, 1983), xi [emphasis added].

24 Z. Bou-Zeid, "Unwelcome but Tolerated: Irregular Migrants in Canada" (Diss. Osgoode Hall Law School, York University, Toronto, 2007).

25 D. Galloway, "Noncitizens and Discrimination: Redefining Rights in the Face of Complexity," in Of States, Rights, and Social Closure: Governing Migration and Citizenship, ed. O. Schmidke and S. Ozcurumez (New York: Palgrave Macmillan, 2008).

26 Hannah Arendt, The Origins of Totalitarianism (San Diego, CA: Harcourt, Brace, 1967), 296.

27 D. Stasiulis, "International Migration, Rights, and the Decline of 'Actually Existing Liberal Democracy," Journal of Ethnic and Migration Studies 23, 2 (1997), 197.

28 Cohen, Migration and Its Enemies. 
migration as a process whose genesis lies outside Canada, in which migration occurs for reasons unrelated to the operation of Canada as a self-contained nation, and in which Canada is "saddled with the task of accommodating this population"-hence the fixation on the legitimacy of entry and the fear of intrusion. ${ }^{29}$ The deployment of sovereignty to justify the differential application of rights and entitlements for precarious migrants in Canada thus promotes the fiction of immigration as an "exogenous process" to which the state is a passive respondent. ${ }^{30}$ To the contrary, the active role of the Canadian economy in temporary labour migration, and its increasing reliance thereon, is clear in the development of specific recruitment-based programs for agriculture, domestic work, and low-skilled work; the increasing numbers of workers recruited in these programs; the long-term dependence on workers with short-term permits; and the absence of any prescribed limit on the number of employer-based work permits. Rather than framing labour migration as a flow to be stemmed from outside the state or penalized within it, using precarious migration as an organizing concept leaves room for a dynamic understanding of labour migration, in which the legal/institutional production of precariousness is a function of the Canadian social and economic system itself. ${ }^{31}$

\section{The Expansion of Migrant Precariousness in Canada}

Using migrant precariousness as a binding characteristic, this section assembles information from government data on tax returns, temporary migrant worker programs, the inland refugee claims process, enforcement numbers, and available estimates of the undocumented population. With this constellation of data and analytical framework as the backdrop, the second part of this section assesses the law's relationship to the creation of precarious migrant populations by way of example, using recent large-scale changes to the refugee system and temporary work programs.

One of the few overall measurements useful for painting a broad picture of temporary residents' engagement with the labour force is the Canada Revenue Agency's record of individual tax filers whose returns are based on a temporary Social Insurance Number (SIN). Table 1 shows an increase in the number of people non-permanent tax returns filed by year; this number represents individuals who are working and paying taxes, but have a temporary SIN (generally issued to those on work permits or otherwise lacking permanent status).

Although these data do not capture exactly the number of precarious migrants (because they do not include undocumented workers or anyone working without a SIN), they provide a conservative baseline of the number of non-permanent migrants in the workforce, a majority of whom fall within the categories listed below.

\footnotetext{
S. Sassen, Guests and Aliens (New York: New Press, 1999), 136.

Ibid.

Ibid., 134.
} 
Table 1

Number of non-permanent tax returns (individual tax filer)

\begin{tabular}{lccccccc}
\hline Year & 2004 & 2005 & 2006 & 2007 & 2008 & 2009 & 2010 \\
\hline $\begin{array}{l}\text { Number of } \\
\text { non-permanent } \\
\text { tax returns }\end{array}$ & 193,250 & 202,420 & 207,960 & 244,350 & 295,290 & 322,580 & 338,840 \\
\hline
\end{tabular}

Source: Data released to the author by the Canada Revenue Agency (CRA) on March 23, 2011, as part of Access to Information (ATI) Request A-054461 and on March 26, 2012, as part of ATI Request ATIP-058334, requesting numbers of individual tax filers with a SIN starting with the number 9, which denotes persons who are neither citizens nor permanent residents.

\section{A. The Shape of Precariousness: Temporary Foreign Workers, Refugee Claimants, and Undocumented Migrants}

This section focuses on the three status categories of migrants: temporary foreign workers, inland refugee claimants (with or without work authorization), and undocumented migrants. As described in specific detail below, each of these groups fits under the rubric of precarious migration status. Furthermore, they serve as a focal point because, on the basis of numbers, they constitute the vast majority of precarious migrants in Canada. ${ }^{32}$

\section{i. Temporary foreign workers}

Based on available data, temporary foreign workers make up the largest proportion of precarious migrants in Canada, and their numbers have grown considerably over the past 10 years. ${ }^{33}$ In 2010 , for example, 182,322 temporary foreign workers entered Canada. ${ }^{34}$ Furthermore, as Figure 1 shows, the proportion of workers classified as "low skilled" has been increasing.

Temporary foreign workers experience several of the characteristics of precariousness identified by both Vosko and Goldring: they do not possess the permanent right to enter and reside in Canada, and they have differential access to statutory entitlements and to work-related rights such as collective

32 Although a perfect data comparison is not available because of the lack of data on the number of undocumented migrants in Canada, and also because of the likelihood that people are working without SINs, the CRA data give a rough low estimate of the number of precarious migrants with status of some kind, of which the number of refugee claimants and the number of temporary foreign workers would cumulatively form a majority. Undocumented migrants are included not only because of the number of migrants with this status but because of the particular risks associated with absolute lack of migration status.

33 Temporary work permits are issued pursuant to labour-specific programs, such as the Seasonal Agricultural Worker Program and the Live-in Caregiver Program, as well on the basis of individual employment relationships in both high- and low-skilled categories of labour. Temporary work permits may also be issued to people who are awaiting the finalization of their permanent residence under humanitarian, refugee, or spousal sponsorship; to students; and to spouses of authorized workers and students.

34 Citizenship and Immigration Canada, Facts and Figures-Preliminary Tables: Permanent and Temporary Residents, 2010 (Ottawa: Citizenship and Immigration Canada, Research and Statistics, 2011), http://www.cic.gc.ca/english/resources/statistics/facts2010preliminary/03.asp. 


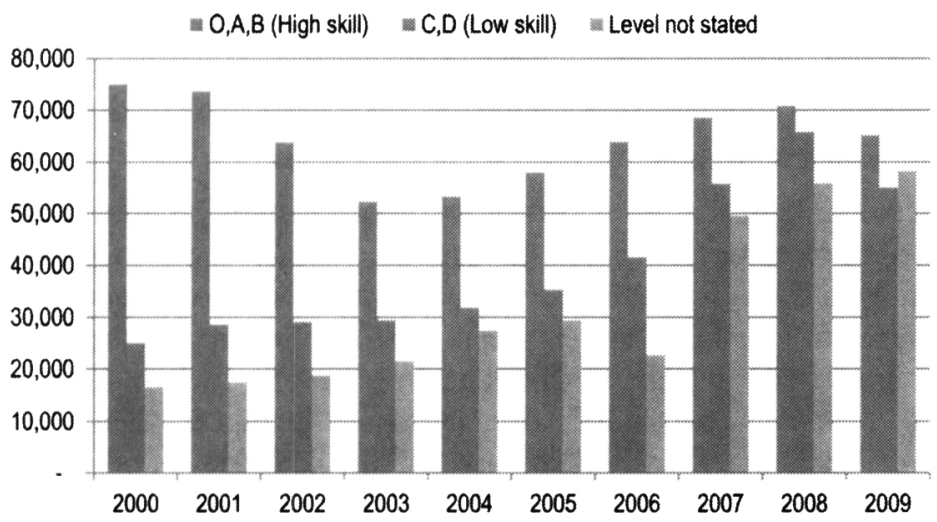

Figure 1 Work permits issued by skill level

Source: Citizenship and Immigration Canada, Facts and Figures 2009-Immigration Overview: Permanent and Temporary Residents: Total entries of foreign workers by gender and occupational skill level (Ottawa: Citizenship and Immigration Canada, Research and Statistics, 2010), http:// www.cic.gc.ca/english/resources/statistics/facts2009/temporary/11.asp

organizing. Many temporary foreign workers are permitted to work only for the employer specified on their work permit; ${ }^{35}$ they depend on that employer for their status and are unable to circulate freely in the labour market, which imposes a relative disadvantage in bargaining power. Some workers, most notably live-in caregivers and agricultural workers, cannot leave their place of residence as a condition of their work permit. Workers classified as "high skilled" are much more likely to obtain permanent residence through federal and some provincial programs ${ }^{36}$ than those classified as "lowskilled," despite the length of time for which the latter may have contributed to the Canadian economy or resided in Canada. Foreign workers are legally entitled to participate in provincial health insurance and to register their children in school, have access to employment-standards and human-rights remedies, and may obtain workers' compensation. Although they pay into federal employment insurance, however, they are often unable to qualify for its benefits, since they are not considered "available for work" because of their bonded work-permit status. ${ }^{37}$ Temporary foreign workers generally do not have access to provincial social-assistance benefits. For some workers, specifically those entering Canada pursuant to agriculture-specific programs,

35 Immigration and Refugee Protection Regulations, SOR/2002-227, ss 183(1)(b), 185(b)(ii).

36 Although the vast majority of low-skilled workers do not qualify for permanent residence under federal economic classes, there are provincial initiatives underway to provide permanent residence to a number of low-skilled workers: see, e.g., British Columbia's Entry-Level and Semi-Skilled pilot program (http://www.welcomebc.ca/wbc/immigration/ come/work/about/strategic_occupations/entry_level/who.page?WT.svl=LeftNav) and Manitoba's Provincial Nomination Program (http://www.immigratemanitoba.com/how-toimmigrate/eligibility/).

37 S. Elgersma, Temporary Foreign Workers (Ottawa: Political and Social Affairs Division, Library of Parliament, 2007), 4. 


\section{Sarah Marsden}

the right to bargain collectively has been sharply curtailed by the recent Supreme Court of Canada decision in Fraser. ${ }^{38}$

\section{ii. Inland refugee claimants}

Refugee claimants fit within the rubric of precariousness because they do not have the right to enter and remain in Canada ${ }^{39}$ but also because of their relative position in the labour market. No quantitative data are available to indicate the types of jobs filled by refugee claimants, but for the purposes of this article it is assumed that many claimants are working in jobs that would be considered relatively "low skilled," or generally requiring less than a university education. This is particularly likely because the countries of origin for most claimants would preclude direct application of foreign-earned credentials in Canada, even for those who have a post-secondary degree or professional designation, effectively deskilling them upon entry to the Canadian labour market. ${ }^{40}$ Refugee claimants are entitled by law to obtain an open work permit, access to health care, and basic services such as education and social assistance while they await determination. The degree to which refugee claimants participate in the labour market is not specifically recorded, but a high labour-market participation rate can be assumed based on the numbers of work permits issued to claimants.

Canada signed the Convention Relating to the Status of Refugees in 1969, 18 years after the convention's adoption by the United Nations. By 1973, the Immigration Appeal Board was legally enabled to hear deportation appeals on the basis of bona fide refugee claims in Canada. In 1980, 1,600 refugee claims were made from within Canada; by 1988 the number had increased to

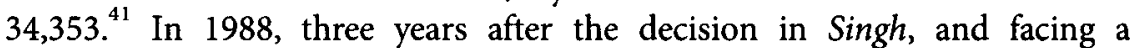
backlog of more than 80,000 claimants, the government started a regularization program, and on a rolling basis about 160,000 migrants were regularized by 1992. In 1987, Canada ratified the Convention Against Torture, which led to the expansion of protection pursuant to Canada's obligations at international law. The number of inland claims has remained high through the 1990s and into the last decade, as has political and public interest in debating the genuineness of refugee claims and thus the legitimacy of the claimants within Canada. Here I consider the claimant population already in Canada as a subset of the precarious population on the basis of contingency of status, actual residence in Canada, and participation in the labour market and the Canadian social state. As Table 2 shows, over the past 10 years, the number of inland claims per year has ranged from under 20,000 to almost

38 Ontario (AG) v Fraser, 2011 SCC 20.

39 This is underscored by the fact that each person claiming refugee status in Canada is issued a deportation order when a claim is made, which disappears only if the claim is successful: Immigration and Refugee Protection Regulations, SOR/2002-227, ss 228(3), 206(a).

40 See, e.g., S. Chan et al., The Profile of Absolute and Relative Homelessness Among Immigrants, Refugees, and Refugee Claimants in the GVRD: Final Report (Vancouver: MOSAIC, 2005).

41 S.N. Azaad, "Resolving the Backlog: An Analysis of Canada's Refugee Backlog Clearance Program" (Toronto: York University Department of Political Science, RSC/SC-44.2, 1991). 
Temporary Migrants and the Law in Canada 219

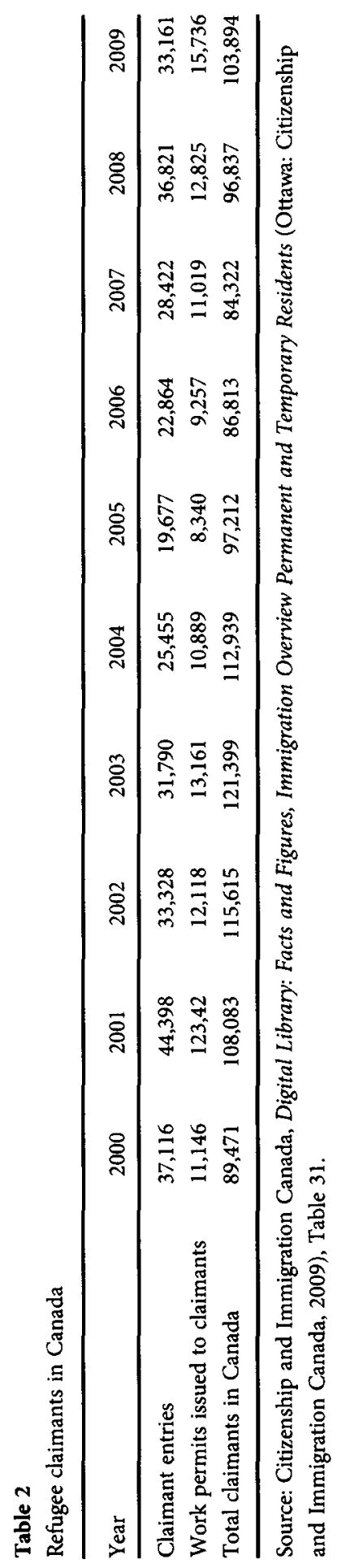


45,000 ; the number of claimants with unresolved cases in Canada at any given time has generally been at least 80,000, and as of the end of December 2009 there were more than $100,000 .^{42}$

Thus, refugee claimants make up a significant portion of the precarious migrant population in Canada likely to have a high labour-market participation rate in low-skilled work, and with relatively strong labour mobility and access to the social state but extremely limited security of status.

\section{iii. Undocumented migrants}

Undocumented migrants represent the extreme of precarious migration status: they neither have the right to enter and remain in Canada, nor are they able to gain access to the vast majority of social benefits and entitlements. Furthermore, they are likely to be at risk of poor labour conditions, low labour mobility, and difficulty obtaining protection in the employment relationship because of fear of enforcement. In Canada, in contrast to the United States, there are currently no precise data on this group, and little in the way of specific law or policy beyond the basic prohibitions on working or hiring a worker without a permit. ${ }^{43}$ Recent hearings and a subsequent report issued by the House of Commons estimate the number of undocumented workers in Canada at between 50,000 and 800,000 . The report notes that undocumented migrants are "are vulnerable to marginalization and mistreatment" but offers no analysis except the general recommendation to "stop the problem from getting any bigger." Although quantitative data do not exist, it is likely that a majority of undocumented migrants participate in the labour force, particularly given the material necessity that flows from their almost universal lack of entitlement to services. Without documentation, such migrants must rely on the variable policies of specific agencies, and even then the fear of deportation or isolation can prove a formidable barrier. ${ }^{45}$ There is anecdotal evidence to indicate that much work performed by workers without status would be categorized as low skilled. ${ }^{46}$ Although some undocumented migrants enter Canada undetected, most likely enter with legal status of some kind and then maintain residence in Canada after that status expires. Furthermore, the structure of immigration law produces migrant precariousness in part via removal of status or the threat of enforcement: if it is difficult to renew work permits or to switch employers, for example, a worker may continue in a job without status, and an employer

42 Citizenship and Immigration Canada, Digital Library: Facts and Figures, Immigration Overview Permanent and Temporary Residents (Ottawa: Citizenship and Immigration Canada, 2009), Table 400.

43 Immigration and Refugee Protection Regulations, SOR/2002-227, s 183(1)(b); Immigration and Refugee Protection Act, SC 2001, c 27, ss 124(a), 124(c).

44 D. Tilson, Temporary Foreign Workers and Nonstatus Workers (Report of the Standing Committee on Citizenship and Immigration) (Ottawa: Library of Parliament, 2009), 65.

45 L. Magalhaes et al., "Undocumented Migrants in Canada: A Scope Literature Review on Health, Access to Services, and Working Conditions," Journal of Immigrant and Minority Health 12, 1 (2010), 132.

46 Anderson, "Migration, Immigration Controls and the Fashioning of Precarious Workers." 
may willingly hire her. Because migrants may be without legal status before or after a period of regular status, the undocumented population interacts dynamically with the temporary worker and inland refugee programs in the institutional production of migrant precariousness.

\section{B. Assessing Recent Changes to Refugee and Temporary Work Programs}

This section focuses on two recent changes to immigration law: the reconfiguring of the refugee system through the introduction of the Balanced Refugee Reform Act in 2010, amending the Immigration and Refugee Protection Act, and amendments to the Immigration and Refugee Protection Regulations that took effect on April 1, 2011.

Although both of these changes invite direct critique on the basis of international and domestic human-rights standards, this section aims specifically to interrogate their potential effect on the precarious migrant population in Canada, in terms of both numbers and the degree of precariousness likely to be experienced. This discussion relies on several insights flowing from migration scholarship on a global level: that economic demand in the host country is a primary determining factor of migration flows; that economic disparity between nations creates conditions in which migrants concede to working conditions inferior to those expected by permanent residents; and that other factors, such as state policy and migration networks, function to catalyse these economic preconditions in specific patterns. ${ }^{47}$ Employing the notion of precarious status as a common axis for both inland refugee and humanitarian and labour-based temporary migration, this section aims to trace the emerging shape of such patterns in the Canadian context, with the aim of inviting an embedded analysis of the law.

\section{i. Changes to the inland refugee and humanitarian process}

In June 2010, Bill C-11, otherwise known as the Balanced Refugee Reform Act, was passed into law, to be implemented over the following two years. This legislation is likely to affect migrant precariousness by application to migrants already in Canada through both the preclusion of status and the disruption of status. ${ }^{48}$ With respect to preclusion of initial status, the law enables the government to designate categories of migrants, on the basis of country of origin, for expedited processing and more stringent appeal deadlines within the refugee process. Alongside the criticism that this amendment is contrary to Canada's obligations at international law because it provides differential protection to refugees who may fit within the Refugee Convention definition is the bare fact that it will create a second tier of refugee protection applicable to large numbers of potential claimants. Should Mexico, for example, be

47 Sassen, Guests and Aliens, 134.

48 Although refugee claimants do not have status in Canadian migration law for the purposes of, for example, accruing work experience toward permanent residence, they do possess an identification document as refugee claimants, and are entitled to various social benefits on this basis; for the purposes of this analysis, to distinguish them from migrants entirely without status, refugee claimants are thus considered to have a form of migration status. 
designated as a country from which nationals cannot apply for refugee protection, thousands of Mexican migrants would have reduced access to the refugee process in addition to being unable to obtain other forms of temporary status from inside Canada. If migration flows continue on the basis of political and economic context, this measure will increase the degree of precariousness for migrants who would otherwise be within the refugee system, as well as potentially increasing the number of migrants who have no opportunity to regularize permanently. With respect to discontinuity of status, this law also contains specific prohibitions on further applications for individuals whose refugee claim has been refused, withdrawn, or declared abandoned: if a person falls within the latter category, she may not apply for a temporary resident permit or pre-removal risk assessment within 12 months of the triggering event in the refugee process. ${ }^{49}$ This change breaks the continuity in status that was previously available. Under the new regime, people who are denied refugee status will be able to apply for further remedies only after the passage of 12 months, during which time they will be without status if they remain in Canada. This will increase precariousness for a group of migrants who have not yet exhausted their legal remedies in Canada but who also cannot obtain work authorization and the associated entitlements. Given the many factors that influence migration, it is by no means guaranteed that this measure will induce migrants to leave Canada; some may do so, but for the remainder the effect will be to increase precariousness. It is difficult to determine the number of migrants likely to be affected by this section of the legislation, but current numbers indicate that over $50 \%$ of cases heard are refused; for example, there were about 4,000 refusals (not taking account of withdrawn or abandoned claims) in $2008 .^{50}$ Given the low rate of enforcement, as well as the economic and political factors that may lead migrants to remain in Canada, these changes are likely to further increase the proportion of migrants with precarious status, and to push refugee claimants into a situation of greater precariousness by making it more difficult to maintain status.

Furthermore, the federal government has recently proposed amendments to the Immigration and Refugee Protection Act that will severely impair the capacity of inland refugee claimants to obtain regular, permanent status. Pursuant to the Preventing Human Smugglers from Abusing Canada's Immigration System Act, ${ }^{51}$ the minister of citizenship and immigration has broad discretion to categorize foreign nationals as "designated foreign

49 Pursuant to s 24(4) of the Immigration and Refugee Protection Act (already in effect), a person "may not request a temporary resident permit if less than 12 months have passed since their claim was last rejected or determined to be withdrawn or abandoned"; pursuant to the new s 112(3) of the amended Immigration and Refugee Protection Act (in effect as of June 2012), pre-removal risk assessment will not be available for 12 months after a claim for refugee protection has been withdrawn, refused, or abandoned. An Act to amend the Immigration and Refugee Protection Act, s 15(3), http://www.parl. gc.ca/HousePublications/Publication.aspx?Docid $=4617288 \&$ file $=4$.

50 Sean Rehaag, "2008 Refugee Claim Data and IRB Member Grant Rates (Canadian Council for Refugees, 2009), http://ccrweb.ca/documents/rehaagdatamarch09.htm.

51 Bill C-4, An Act to amend the Immigration and Refugee Protection Act, the Balanced Refugee Reform Act and the Marine Transportation Security Act, 1st Sess, 41st Parl, 2011, 
nationals" if they are seen as having entered Canada via "irregular arrival." The minister has extremely broad powers under this section: an arrival may be considered irregular wherever "examinations of the persons in the group cannot be conducted in a timely manner" or where the minister

(b) has reasonable grounds to suspect that, in relation to the arrival in Canada of the group, there has been, or will be, a contravention of subsection 117 (1) for profit, or for the benefit of, at the direction of or in association with a criminal organization or terrorist group. ${ }^{52}$

Section $117(1)$ prohibits the involvement of any person (Canadian citizen, permanent resident, or foreign national) in actions that result in the unlawful entry of persons into Canada, whether by actual knowledge or by being "reckless as to whether" those persons would be entering unawfully. ${ }^{53}$ The wording of these sections is very broad, and would include any situation in which a person has provided, or may provide, money for services that lead to entry into Canada or in which a "criminal organization" is involved, no matter the circumstances-and for any potential contravention of the act. Many people arrive in Canada without appropriate documentation to make refugee claims: by definition, people who are forced to leave by threats or persecution are not likely to have proper documentation or advance permission to enter Canada. The Immigration and Refugee Protection Act specifically recognizes this in $s 133$, which excludes refugee claimants from prosecution for the document-based offences listed in $s 122$ and related offences. ${ }^{54}$ Furthermore, people who have no obvious way to enter Canada but are desperate to do so regularly pay fees to smugglers, recruiters, or other parties; many such people would be captured by the language of the proposed changes even if they are not knowingly involved in contravening the act. The consequences of being labelled a "designated foreign national" are immense and represent a radical change in refugee policy. Those "designated" cannot make an application for permanent residence for a period of five years after the disposition of their claim, even if it is positive, and are similarly barred from applying for a temporary residence permit for five years. ${ }^{55}$ This means that recognized Refugee Convention refugees and protected persons who meet the threshold set in international and domestic law are stripped of the rights associated with permanent residence, including mobility and family reunification, while at the same time their status remains precarious and dependent for a protracted period, on a punitive basis. Furthermore, "designated" persons are subject to mandatory detention provisions and are categorically excluded from appeal rights to which other refugee claimants

http://www.parl.gc.ca/HousePublications/Publication.aspx? Language=E $\&$ Mode $=1 \&$ DocId $=$ $5093718 \&$ File $=30 \# 2$.

52 Ibid., 5 .

53 Ibid., s $18(1)$.

54 Immigration and Refugee Protection Act, SC 2001, c 27, s 133.

55 An Act to amend the Immigration and Refugee Protection Act, http://www.parl.gc.ca/ HousePublications/Publication.aspx? Docid $=4617288 \&$ file $=4$, ss $5-7$. 


\section{Sarah Marsden}

have access. ${ }^{56}$ In addition to the potential Charter and other rights-based challenges to this legislation, should it pass, Bill C-4 has the potential both to increase the numbers of precarious migrants who are unable to regularize and to deepen the precariousness of refugee claimants through a range of detrimental effects on social membership that would be the direct result of inability to regularize.

\section{ii. Changes to the temporary foreign worker program}

Starting in April 2011, several fundamental changes to the legal regulation of temporary foreign workers in Canada came into effect $^{57}$ that are of specific concern with regard to increasing migrant precariousness, in particular through the new cumulative limit of four years. Previously, temporary foreign workers in Canada were not subject to any regulatory limit on the length of their stay; so long as they met the requirements for the work permit, they were able to remain in Canada indefinitely on the basis of renewed permits. Now, with several exceptions, foreign workers will be limited to a cumulative four-year period of work in Canada, after which they will be able to obtain temporary status in Canada only after a waiting period of a further four years.

As described above, the temporary foreign worker program in Canada divides workers into "high-skilled" and "low-skilled" categories; the latter constitutes an increasingly large share of total temporary foreign worker entries to Canada. Access to permanent residence in Canada is biased categorically in favour of workers whose labour is categorized as "high-skilled," because the requirements for such work often qualify such workers for permanent residence; the majority of "high-skilled" workers would likely be eligible for permanent residence within the four-year time period if they so wished. "Low-skilled" workers, on the contrary, are generally ineligible for permanent residence." As a result, this legal shift is likely to affect lowskilled workers disproportionately, not only because they lack access to permanent regularization but also because of their potential to lose status through the cumulative time period. Further changes to the Regulations concerning foreign workers include the denial of work permits to employees on the basis of the employer's previous lack of compliance or discrepancies with the original job offer. As I have argued elsewhere, this change risks placing a

Ibid., ss 10(2), 17.

Immigration and Refugee Protection Regulations, SOR/2002-227, ss 200(1)(c), 200(2)(g), $200(2)(\mathrm{h})$.

58 Another recent policy change has seen "high-skilled" migrants in Canada as PhD students at Canadian universities obtain more direct access to permanent residence as Federal Skilled Workers, a category to which migrants whose labour is classified as "low-skilled" are categorically denied access: Citizenship and Immigration Canada, "Fourth Set of Ministerial Instructions: New PhD Eligibility Stream under the Federal Skilled Worker Program" (Operational Bulletin 351, November 4, 2011), http://www.cic.gc.ca/english/ resources/manuals/bulletins/2011/ob351.asp.

But see provincial nomination programs discussed in note 37. 
disproportionate burden on workers rather than on employers. ${ }^{60}$ Although the articulated aim of these changes is to protect temporary foreign workers, their combination with the existing system of single-employer bonded work permits means that foreign workers bear the cost of employers' problems, since they will be at greater risk of loss of status on the basis of noncompliance by their employers. Thus, precariousness may be increased in the temporary foreign worker population both through the inability to extend or renew permits beyond four years and through loss of status as a result of employer non-compliance.

\section{The Role of Enforcement}

Both in policy and in practice with regard to precarious migrants, enforcement is used as an expression of the state's limitation of migrants' capacity to reside legally in Canada, as well as of other rights within the state. Insofar as precarious or temporary migration is constructed as a problem, the idea of enforcement is readily enlisted as the solution. In the Canadian context, however, enforcement of limits on precarious migrants already present in Canada appears to function primarily on a symbolic level. The number of prosecutions and deportations of irregular migrants is small relative to the likely number of migrants without status or with improper documentation, and enforcement against employers of precarious migrants has also been ineffective at best. ${ }^{61}$ Talk of the dangers of large-scale incursions of migrants, both workers and refugees, persists in policy discourse. ${ }^{62}$ In practice, then, large-scale enforcement has not been actively pursued by the state, but the idea of enforcement is symbolically entrenched in the context of precarious migration through the conflation of two quite different issues: border control and migrant control. The former term refers to controlling the entry of persons into a state, often cited as a foundational aspect of sovereignty; the latter refers to the regulation of persons who are already within the state's territory and whose presence gives rise to specific normative claims to membership that do not exist for those outside the state's borders. ${ }^{63}$ In other words,

60 S. Marsden, "Assessing the Regulation of Temporary Foreign Workers in Canada," Osgoode Hall Law Journal 49, i (2011).

61 J. Fudge and F. MacPhail, "The Temporary Foreign Worker Program in Canada: LowSkilled Workers as an Extreme Form of Flexible Labour," Comparative Labour Law and Policy Journal 31 (2009), 5.

62 For example, the following passage appears in an intelligence manual aimed at educating Canada Border Services Agency officers in carrying out their duties: "In a prolonged recession and difficult labour market, Canada, which has been identified as being better positioned to weather the recession, and with its comprehensive social safety nets, will continue to be an attractive destination for displaced migrant workers and irregular migrants leaving behind social and political conflicts." Canada Border Services Agency, The Impact of the Global Recession on Migration (Ottawa: Canada Border Services Agency, Intelligence Risk Assessment and Analysis Divison, Intelligence Directorate, 2009), 1. This document was released as part of Access to Information Request A-200908262.

63 See, e.g., J. Carens, Immigrants and the Right to Stay (Cambridge, MA: MIT Press, 2010); S. Legomsky, "Portraits of the Undocumented Immigrant: A Dialogue," Georgia Law Review 44 (2009), 65. 
temporary and precarious migrants within Canada are socially and politically excluded on the basis of sovereignty, even while they participate in economic and social communities within the state. Marginalization of precarious migrants within the state is justified by a logic that appeals to sovereignty, borders, and national integrity, but in reality the borders are constructed within, rather than outside, the state, through increasing migrant precariousness and the associated erosion of relative equality. It follows that a strong enforcement response to increasing migrant precariousness is not only ineffective but also highly undesirable from the perspective of a liberal democracy. In the fifth and final section of this article, I briefly outline the foundation for an alternative response to migrant precariousness that more fully addresses the social and economic context in which it occurs and encourages an embedded understanding of the historical and current roles of law and of the Canadian state.

\section{Refiguring the Right to Stay}

The shift toward an economic nexus of permanent membership was concurrent with an ostensible liberalization of migration policy and an increase in the proportion of precarious migrants in the workforce, and there is good reason to believe that legal structures will continue to produce or increase migrant precariousness. This pattern underscores the contrast between the liberal values purported to be foundational to Canada's migration system and the application of neo-liberal economic policies in a manner that effectively disjoins economic participation from social and political membership for an increasing number of migrants. As described above, the liberalizing shift was signified primarily by laws that were no longer racist and that universalized the economic basis of membership through such programs as the points system, swiftly followed by the permanent establishment of temporary migrant work programs in which a racialized subclass of migrant labour is produced. ${ }^{64}$ This subclass is maintained in current policy, and it has grown to constitute a large proportion of the labour force through precarious migration, consisting primarily of temporary workers, refugee claimants, and undocumented migrants. The nature of the work done by precarious migrants is also telling: under conditions of globalization, labour is commonly outsourced to jurisdictions with lower labour costs in order to increase profit, but certain types of labour cannot be relocated-notably in agriculture, construction, service, and domestic work, all major labour segments for precarious migrants working in Canada.

Canada's historical and current migration policy, despite its lack of overt racism, is difficult to describe as a true expression of liberal values, because unequal distribution of membership benefits on the basis of legal distinctions tends to create what Robin Cohen calls a "helot" class, separate from citizens and other permanent residents. This group of workers can also be understood

64 Sharma, "On Being Not Canadian," 425. 
as providing a cohort of unfree labour as a necessary balance to free labour within capitalist economic systems, in which employers benefit from flexible labour provided through migration. ${ }^{65}$ Thus, we should rethink policy and advocacy arguments that rely on the premise of liberal values which, however desirable, do not provide a complete explanation for the basis and purpose of migration law in Canada. Inverting this logic, I suggest that in our construction of migrant rights we seek instead to comprehend and respond to the underlying, and often functionally illiberal, economic basis for specific iterations of migration law.

If migrant precariousness is produced as part of the "cost" of a liberal migration policy in which the law functions to stratify migrant workers via exclusion from permanent residence in line with an economic need for flexible migrant labour, advocacy and policy responses will be most effective if they aim to re-embed migrant rights within an economic context in order to rejoin economic participation with social and political membership. This means finding an approach that considers the historical basis and effect of migration policy and that responds in specific terms to the economic and social conditions that precipitate migrant labour. Liberal approaches in favour of migrant rights on the basis of residence-in the work of Joseph Carens, for example-provide a compelling argument for the inclusion of migrants on a moral basis, arguing that such inclusion is necessary in various iterations of the liberal tradition. The elucidation of liberal theory to support the inclusion of migrants on par with citizens in self-identified liberal democracies promotes desirable aims, whose appeal is only increased in light of the global trend toward impermanent, insecure migration and the increased polarization of wealth within the global order. These very factors, however, also invite reconsideration of the initial premise of "our liberal democratic tradition," ${ }^{\text {"66 }}$ particularly with regard to labour migration. But if the basis of migrant exclusion and precariousness flows not only from the liberal tradition but also from the neo-liberal economics that accompanied the liberal shift in the Canadian context, arguments in favour of regularizing migrants require a critical approach to both liberal values and the realities of neo-liberal policy. The argument for the full and permanent inclusion of migrants could be made on the basis of economic participation. The most obvious starting point for such a response is the economic nexus of permanent membership; although, in Canadian law, permanent residence is not quite citizenship, ${ }^{67}$ it provides labour mobility, social entitlements that are curtailed for precarious migrants, and the right to enter Canada and remain there on a permanent basis. The current basis for

65 Cohen, Migration and Its Enemies.

66 J. Carens, "Aliens and Citizens: The Case for Open Borders," Review of Politics 49 (1987), 268.

67 In brief, permanent residents have the right to enter and remain in Canada, to circulate freely in the labour market, and to access the same social and economic benefits as citizens. Unlike citizens, however, they are subject to residency requirements in order to maintain their status and sponsor relatives, may be deported or detained for serious crimes or security issues, and cannot vote in most elections. 


\section{Sarah Marsden}

selecting and excluding migrants relies largely on an ostensible assessment of the potential for economic contribution, and those with work experience classified as "high-skilled" are able to obtain legal permanent residence with ease. However, the increasing number of precarious migrants working in jobs classified as "low-skilled," as well as the long-term necessity of such work despite state insistence on the temporary nature of work programs, provides evidence of the increasing necessity of such work to the Canadian economy. ${ }^{68}$ In other words, rights for precarious migrants can be made out analogously to the existing economic nexus of membership in Canadian migration law in an attempt to resist the construction of "Other" migrants that has been prevalent in the development of the economic nexus thus far. For example, demonstrating the economic necessity of "low-skilled" work, in which precarious migrants are overrepresented, and the disparity of treatment between such a worker and a "high-skilled" migrant accepted for permanent residence on the basis of his or her potential economic contribution would embed an egalitarian approach within the specific economic context. In advocating this approach, I by no means intend to imply that neo-liberalism is a socially or economically viable program; I hope, rather, to encourage legal and policy responses in which the economic basis for labour migration is deployed in support of expanding, rather than constraining, membership entitlements for precarious migrants.

Because the economic necessity and contribution of precarious migrants in "low-skilled" work can be clearly established, I would argue that their claim to permanent residence and associated entitlements is well founded as a direct expansion of existing principles of migration law on the basis of the economic nexus of membership. Furthermore, this approach provides a powerful counterpoint to the exclusion of such migrants from within Canada on the basis of symbolic sovereignty, and thus can be articulated as a form of "post-national" and normative membership claim that "usefully enables us to challenge [the presumption of containment with a nationstate.]" In effect, these migrants are already members of Canadian society by the logic of economic necessity, which has been the linchpin of permanent migration programs. Such an approach has the potential not only to reconnect economic contribution with membership benefits but also to embed our understanding of migration law within a globalizing economic context and corresponding labour-migration patterns that are increasingly precarious.

\section{Abstract}

In this article, I argue that precarious migration status can be used as an organizing concept for an analysis of (im)migration law in Canada. After situating the regulation of precarious migrants in the historical context of the liberal/neo-liberal shift of the

Tilson, Temporary Foreign Workers and Nonstatus Workers, 5.

L. Bosniak, "Citizenship Denationalized," Indiana Journal of Global Legal Studies 7 (1999), 453. 
1970s, I argue that the increase in migrant precariousness over the past few years is likely to increase as a result of recent legislative changes in both refugee and migrant-worker law. Finally, I offer a critique of the traditional liberal argument for migrant rights, inviting an alternative approach to establish migrant rights on the basis of economic participation.

Keywords: refugee, temporary foreign worker, labour migration, neo-liberalism, employment, welfare state

\section{Résumé}

Dans cet article, je soutiens que le statut précaire d'immigrant peut être utilisé en tant que concept organisateur dans l'analyse des lois sur la migration et l'immigration au Canada. Après avoir situé la réglementation des migrants précaires dans le contexte historique des années 1970 , période marquée par le passage du libéralisme au néolibéralisme, je soutiens que l'accroissement de la précarité des migrants au cours des dernières années pourrait augmenter à la suite des changements législatifs récents apportés aux lois sur les réfugiés et les travailleurs étrangers. Finalement, je porte un regard critique sur l'argumentation traditionnelle libérale liée à la défense des droits des migrants, et propose une approche alternative afin d'établir les droits des migrants sur la base de leur participation économique.

Mots clés : réfugié, travailleur étranger temporaire, migration de la main-d'œuvre, néolibéralisme, emploi, État providence

Sarah Marsden

PhD Candidate

Faculty of Law

University of British Columbia

1822 East Mall

Vancouver, BC V6T 1Z1 Canada 